\title{
The Risk of Expulsion is Higher in IUD-Endometrium Distance of More than $10 \mathrm{~mm}$
}

\author{
Jarak antara IUD dan Endometrium Lebih dari $10 \mathrm{~mm}$ \\ Berisiko Lebih Besar untuk Terjadinya Ekspulsi
}

\author{
Teguh Senjaya, Freddy W Wagey, Edi Suparman \\ Department of Obstetrics and Gynecology \\ Faculty of Medicine of Sam Ratulangi Univeristy/ \\ Prof. Dr. R.D. Kandou General Hospital \\ Manado
}

\begin{abstract}
Objective: To acknowledge the rate of expulsion in post placental IUD CuT-380A insertion after vaginal delivery.

Method: Postplacental IUD Cu T-380A insertion was performed at least 10 minutes after the placenta has been delivered by inserting IUD Cu T-380A in uterine cavity using index finger, and positioned the IUD in uterine cavity and pushed as high as possible directly to the uterine fundus. Then the IUD-endometrium distances were checked using transvaginal USG on the seventh and forty second day after IUD insertion.

Result: From May and August 2012 has been done post placental IUD Cu T-380A set in 38 women, found that average of women age was $\geq 30$ years old $(34.21 \%)$, multi parities $(63.16 \%)$, and gestation age for $37-42$ weeks $(100 \%)$. In this study found that three expulsion cases. Totally expulsion found in 2 cases, each found in days of 16 with averages distances of IUD and endometrium for $16.8 \mathrm{~mm}$ and in days of 19 with average distances of IUD-ED for $13.5 \mathrm{~mm}$ after IUD set. While partially expulsion found in 1 case, occurred in days of 11 after IUD set with average distance IUD-ED for $13.2 \mathrm{~mm}$.

Conclusion: IUD Cu T-380A set after vaginal delivery that observed for 42 days found that $3(7.89 \%)$ peoples have expulsion. There is significant correlation the distance between IUD and ED in expulsion occurrences.

[Indones J Obstet Gynecol 2013; 37-1: 26-31]
\end{abstract}

Keywords: expulsion, post placental IUD Cu T-380A

\begin{abstract}
Abstrak
Tujuan: Mengetahui kejadian ekspulsi pada pemasangan IUD Cu T-380A pascaplasenta pada persalinan pervaginam.

Metode: Pemasangan IUD Cu T-380A pascaplasenta dilakukan kurang dari 10 menit setelah plasenta lahir dengan cara memasukkan IUD Cu T-380A kedalam kavum uteri menggunakan jari telunjuk dan jari tengah, kedudukan IUD horizontal dalam kavum uteri dan didorong setinggi mungkin ke arah fundus uteri, kemudian dilakukan pengukuran jarak IUD-Endometrium dengan menggunakan USG transvaginal pada hari ke 7 dan ke 42 serta pemotongan benang IUD.

Hasil: Dari bulan Mei sampai dengan Agustus 2012 telah dilakukan pemasangan IUD Cu T-380A pascaplasenta pada 38 orang ibu, didapatkan rerata usia ibu $\geq 30$ tahun $(34,21 \%)$, multipara $(63,16 \%)$, dan usia kehamilan 37-42 minggu (100\%).

Pada penelitian ini terjadi 3 kasus ekspulsi. Ekspulsi total terjadi pada 2 kasus, masing-masing terjadi pada hari ke-16 dengan jarak IUD-ED 16,8 $\mathrm{mm}$ dan hari ke-19 dengan jarak IUD-ED 13,5 $\mathrm{mm}$ setelah pemasangan IUD. Sedangkan ekspulsi parsial terjadi pada 1 kasus, terjadi pada hari ke-11 setelah pemasangan IUD dengan jarak IUD-ED $13,2 \mathrm{~mm}$.

Kesimpulan: Pemasangan IUD Cu T-380A pada persalinan pervaginam yang diobservasi selama 42 hari terdapat 3 orang (7,89\%) yang mengalami ekspulsi. Dan terdapat hubungan yang sangat bermakna antara jarak IUD-ED dengan kejadian ekspulsi.
\end{abstract}

[Maj Obstet Ginekol Indones 2013; 37-1: 26-31]

Kata Kunci: ekspulsi, IUD Cu T-380A pascaplasenta

Correspondence: Teguh Senjaya. Department of Obstetrics and Gynecology. Faculty of Medicine University of Sam Ratulangi/ Prof. R.D. Kandou Hospital, Manado. Mobile: 08129259793 Fax: 0431-859177.

\section{INTRODUCTION}

The period throughout the pregnancy until after delivery is an important period where husband and wife learn about family planning program and become an acceptor of family planning. Currently, information has been given by health care in antenatal care (ANC) session and families are motivated to create a certain time interval between pregnancies. ${ }^{1}$

Post partum period is a problem to women, especially in the developing countries, because most decline to use contraception to prevent unplanned pregnancy. A study of post partum women in 27 demographic area and Health Survey (DHS) for 6 years showed that $40 \%$ of women who intend to use contraception devices for 1 year, in reality turn out to not use contraception. Moreover, only a small percentage of women, i.e. 3\%-8\%, want to postpone having another children until 2 years after delivery, and still 35\% of them become pregnant. Several reasons were unpredictable fertility and sexual activities. And many women don't want to visit health care during parturition period. ${ }^{1}$ 
The number of population continues to increase, and it is a big problem in several countries in the world especially in developing countries. Indonesia is the forth country with the most number of inhabitant. Data in 2000 showed that Indonesia is populated by 203.6 million people with development population rate of $1.49 \%$, meaning that every year, the number of population rise as many as 33.5 million people. If there is no measure taken to control this rate, in 2005 the total population will increase to 293.7 million peoples. $^{2}$

One of the factor causing maternal death, in addition to bleeding, preeclampsia/eclampsia and infection, is high parity, followed by low access to health care. Multiparity does not only impact illness rate and maternal mortality, but also increase the uncontrollable population rate.

Family planning program aims to decrease maternal mortality rate and population growth rate. Family planning program is supposed to decrease maternal mortality risk by decreasing pregnancy rate, and delaying the average age of first pregnancy. ${ }^{3}$

The number of productive-age couple in Indonesia that had successfully been recorded in family planning database in 2007 was 41.256.075. From this number, 1.576 .759 or $3.8 \%$ aged less than 20 years old, 14.207 .561 or $34.4 \%$ aged $20-29$ years old and 25.472 .755 or $61.8 \%$ aged more than 30 years old. ${ }^{4}$

Family planning movement prepared to construct family welfare in order to construct optimal human resources, with feature increase influence and also community by fill access of family planning care. ${ }^{5}$

The number of new participant of family planning in November 2010 was 782.066. From this number, 51.617 participants were using IUD (6.60\%), 7.907 participants were using MOW (1.01\%), which was... initiated in 72.810 participants were using condom (9.31\%), 53.784 participants were using implant (6.88\%), 360.097 participants were using injection (46.04\%), and 234.282 participants were using pill $(29.96 \%) .{ }^{3}$ But based on BKKBN survey, IUD participant in Indonesia has decreased from $10.9 \%$ in $2002-2003$ to $5.4 \%$ in 2006.6

One of the strategy to implement the Family planning program includes Intermediate Range Planning structure (RPJM), initiated in 2004-2009, which focused on increasing long term contraception method (MKJP) like IUD (intra Uterine Device), implant or sterilization. IUD is one of the non-hormonal contraception devices and a long term contraception, ideal to keep an interval of time between pregnancies. The advantage of using an IUD is that it is only inserted once with long term effect and at a relatively cheap cost. It is safe because it doesn't have systemic influence on the body, doesn't affect breastmilk production and the patient's fertility will become normal shortly after the removal of IUD. ${ }^{7}$

Study about IUD in post parturition period showed several variable that has direct result, for example the time of IUD insertion. IUD post placental shows better outcome compared with IUD insertion 10 minutes after placental born. The IUD type, insertion technique, the skill of health care professional and the type of delivery also have great influences. ${ }^{8}$

Post placental IUD insertion has several advantages. The insertion process is not difficult if done by professionals, it could be used by all patients, and it will not cause post partum hemorrhage. It doesn't affect breastmilk production, hormonal balance and not depend on patient's compliance. ${ }^{1,9}$ Copper is the main component of the widely used IUD, and it gives better results and prevents infection. Thus, WHO recommends using IUD $\mathrm{Cu}$ T380A. ${ }^{1}$

Several researchers said that health care exerted great influences in patient's decision to use IUD. ${ }^{10}$ Thus it is important for health care professional to make a bigger effort to increase the number of IUD participant, for example by persuading the woman to have IUD inserted after birth before leaving the hospital. ${ }^{11}$

The idea of IUD insertion right after placental birth (IUD postplacental) was originated from the World Health Organization (WHO). By theories, this would be ideal, since it is relatively cheap, allows the patient to have sexual intercourse safely and has little to no side effect. IUD insertion is performed soon after placenta is born and followed up afterwards. In 1983 and 1996, WHO has just determined this method, however this technique actually was reported first in 1967.8,12

The efficacy of IUD contraception depends largely on its position intrauterine. The correct position would be more effective in preventing con- 
ception compared with if IUD is positioned nearer to the cervix. In the first patient's appointment to follow up after IUD insertion, it is recommended to pay attention to the risk of the change of IUD's position and expulsion of the IUD. ${ }^{13}$ Follow up should be performed in 4-6 weeks after IUD insertion. Anamnesis, gynecology examination and self-examination are all necessary to properly locate the IUD. ${ }^{1}$

Nowadays USG is used routinely in post IUD insertion follow up. Wih USG, IUD position is indicated with the distance between IUD with endometrium in fundus uterine. ${ }^{2}$ Fernandes stated that USG is useful and reliable in examining the position of IUD intra uterine after post placental IUD insertion. ${ }^{8}$ Gabriele S. Merki Feld used USG trans vaginal to estimate IUD-endometrium distance (IUD-ED: the IUD-endometrium distance) in study which compared partial expulsion occurrence and complete expulsion in insersion of 2 kind of IUD i.e. multiload 374 with LNG-IUD. ${ }^{14}$ The distance of IUD-endometrium is a relevant factor in determining the correct position of IUD. ${ }^{13,15-17}$

So far, only few studies had been done in Indonesia to estimate the occurrence of expulsion in post placental IUD insertion, thus we feel it is necessary to study the matter and observe whether the IUD-ED distance correlates with the rate of expulsion.

\section{METHOD}

The study objective is to understand expulsion occurrence in IUD $\mathrm{Cu}$ T-380A assembled post placental in vaginal delivery. This study was a cross sectional study. This study was done in Obstetrics and Gynecology Department, Faculty of Medicine, Sam Ratulangi University/Prof. Dr. R.D. Kandou General Hospital in Manado from May to August 2012. Counselling was done to every pregnant women who want to parturition in Prof. Dr. R.D. Kandou General Hospital in Manado.

Patients who fill inclusion criteria and agreed to joint study asking to sign informed consent after receive explanation about study purpose and objective. Post placental IUD $\mathrm{Cu}$ T-380 insertion was done less than 10 minutes after placental was born by inserting IUD $\mathrm{Cu}$ T-380A into the uterine cavity with index finger and midst finger in horizontal position. The IUD was pushed as far as possible.

After IUD post placental has been set, estimation distance of IUD-Endometrium by using trans vagi- nal USG in day of 7 and 42 after cut off IUD yarn. If the patients experienced any complaints, they were advised to come to the hospital as soon as possible. However, if there was no complaint the patients would be followed up on day-42 after IUD insertion.

\section{RESULT}

This study was performed in May 2012 to August 2012 and the subjects were 38 women having post placental IUD $\mathrm{Cu}$ T-380A insertion performed. The patient would be followed up after 42 days or if she had any complaints. Anamnesis, inspeculo examination, IUD yarn cut and USG examination were all performed to determine the IUD position.

Table 1. Study Characteristic Based on Age to Expulsion occurrence.

\begin{tabular}{lrccr}
\hline \hline $\begin{array}{l}\text { Variable } \\
\text { (years) }\end{array}$ & n & \multirow{2}{c}{} & \multicolumn{2}{c}{ Expulsion } \\
\cline { 4 - 5 } & & & Yes & No \\
\hline 19 & 6 & 15.79 & 1 & 5 \\
$20-24$ & 12 & 31.58 & 2 & 10 \\
$25-29$ & 7 & 18.42 & 0 & 7 \\
$\geq 30$ & 13 & 34.21 & 0 & 13 \\
\hline Total & 38 & 100 & 3 & 35 \\
\hline \hline
\end{tabular}

Table 1 showed that from 38 patient followed in the study, most was $\geq 30$ years old (34.21\%) and 20-24 years (31.58\%). Expulsion occured in 1 patient from $\leq 19$ years old group and 2 patients from the 20-24 years old group.

Table 2. Study Characteristic Based on Parity to Expulsion Occurrence

\begin{tabular}{lcccc}
\hline \hline \multirow{2}{*}{ Variable } & \multirow{n}{*}{} & \multirow{2}{*}{} & \multicolumn{2}{c}{ Expulsion } \\
\cline { 4 - 5 } & & & Yes & No \\
\hline Primiparity & 14 & 36.84 & 3 & 11 \\
Multiparity & 24 & 63.16 & 0 & 24 \\
\hline Total & 38 & 100 & 3 & 35 \\
\hline \hline
\end{tabular}

In this study based on number of parity, the most was multiparity group for 24 patients (63.16\%). And 3 cases expulsion symptom in prime parity group. All of study sample belonging to 37-42 weeks of gestational age group (100\%).

Based on education background, most subjects (52.64\%) were high school graduates and most subjects $(94.74 \%)$ did not have an occupation. 
Table 3. Correlation between IUD CuT-380A-Endometrium distance with Expulsion occurrence

\begin{tabular}{|c|c|c|c|c|c|c|}
\hline \multirow{2}{*}{$\begin{array}{l}\text { IUD-ED Distance } \\
\text { (mm) }\end{array}$} & \multicolumn{2}{|c|}{ Expulsion } & \multicolumn{2}{|c|}{ Un expulsion } & \multirow{2}{*}{ Total $\mathbf{n}$} & \multirow{2}{*}{$\mathbf{p}$} \\
\hline & $\mathbf{n}$ & $\%$ & $\mathbf{n}$ & $\%$ & & \\
\hline$\leq 10$ & 0 & 0 & 30 & 100 & 30 & \\
\hline$>10$ & 3 & 37.5 & 5 & 62.5 & 8 & 0.007 \\
\hline Total & 3 & 7.89 & 35 & 92.11 & 38 & \\
\hline
\end{tabular}

No expulsion occurred in subjects with IUD-ED distance of $\leq 10 \mathrm{~mm}$, while there was 3 cases of expulsion in subjects with IUD-ED distance of $>10$ $\mathrm{mm}$. The result from Exact Fischer test gave $\mathrm{p}=$ $0.007(<0.01)$. This showed that there is significant correlation between IUD-ED distance with te occurrence of expulsion.

\section{DISCUSSION}

The main cause of the decreasing IUD user is its side effect. IUD is a non-hormonal contraception that has several advantages that are relatively economical, safe and effective. Recently, National Family Planning program in Indonesia has planned to provide IUD for every fertile couple, especially after birth. The expectation is that the Increasing IUD user will help decrease the maternal mortality rate in Indonesia.

IUD has several advantage compared to other contraceptions. IUD is non hormonal contraception, has long term effectiveness, only need to be inserted once, has no systemic side effect, is economic and gives reversible infertility. However, its common side effects include bleeding, pain leucorrhoea, perforation, infection, and expulsion, which make many women refuse this method.

Based on the study by Xu et al, expulsion occurrence of IUD Cu T-380A insertion was 13.3 per 100 acceptor after 6 months, but there was no case of uterus perforation, infection or lochia in 384 study subjects. ${ }^{10}$ Study of post placental IUD insertion by Summer and Network in 3.791 post partum women concluded that expulsion occur in 6-37 per 1.000 acceptor during 6 months observation. ${ }^{18}$ Tatum et al performed study of post placental IUD $\mathrm{Cu}$ T-380A insertion in 3 countries, which was Belgium, Chile, and Philippines. This study included 300 patient and 292 post placental placement. Observation was carried out for 1 year and they found expulsion in 39 cases $(13.2 \%)$ in interval assem- bled, and for 46 cases in placement assembled (16.2\%). ${ }^{19}$ Celen et al performed study in 235 IUD placement, and carried out 3 times observation, which were on 6 weeks, 6 months, and 12 month after IUD placement. Expulsion rate find for 5.1\% (6 weeks), 7\% (6 months) and $12.3 \%$ (1 year). ${ }^{20}$ From May 2007 to October 2008, Chen et al performed post placental IUD insertion in Magee Women Hospital, Pittsburgh. Fifty subjects had had IUD placed and were observed for 6 months. They found expulsion occured in 12 patients $(24.0 \%)$.

In this study, done from May to August 2012, we performed post placental IUD insertion in 38 subjects. From 38 acceptors, there were 3 cases (7.89\%) of expulsion, each occured in day 12, 11 and 16 after post placental IUD insertion. In three cases, the acceptor experienced cramp in pelvis area since 3-4 days, and spot vaginal bleeding before expulsion. Some of the most common side effect of IUD was bleeding and also cramp in pelvis area several days after the insertion of IUD. In the study performed by Bednarek, from 258 women who had IUD insertion performed, 13 patients (5\%) had expulsion, preceded by bleeding of pelvic cramp. $^{22}$

Based on age group, the most common age group was $\geq 30$ years old group (34.21\%). In all 3 expulsion cases all occur in subjects aged less than 25 years old. This is similiar with epidemiology study performed by Zhang et al in 1606 patients, where 70 patients had expulsion. Zhang said that expulsion occurrence risk was 5.5 in $\leq 19$ years old age group, 2.1 in 20-29 years old age group and 1.1 in 30-34 years old age group. ${ }^{23}$

Expulsion occurrence is also influenced by parity. Expulsion occurs most often in nuliparity women. Ideally, IUD is placed within $6-9 \mathrm{~cm}$ in the uterine cavity. ${ }^{24} \mathrm{~A}$ random study in Mexico compared IUD Cu T-380A Standard (32 $\mathrm{mm} \times 36 \mathrm{~mm}$ ) with smaller ( $23 \mathrm{~mm} \times 29 \mathrm{~mm}$ ) in 780 multi parity 
women, then observed for 1 year. Expulsion rate in standard IUD insertion was 59\%, higher compared to the smaller IUD, which expulsion rate was only $4 \% .^{25,26}$

Study was done by Chen et al, showed that even there is limitation by sample size, however, they said that parity cannot be predictor of IUD assembled successful post placental observed in 6 months (OR $=1.72$ for prime parity, $\mathrm{p}=0.49) .{ }^{21}$ the third expulsion occurrence in this study, all of them occur in prime parity, and this caused long term per vaginam bleeding. More study will be need by using in larger number of sample so correlation of parity with expulsion would be got.

In this study, 38 subject has been assembled with IUD, 7 days after IUD placement find distance between IUD-ED $\leq 10 \mathrm{~mm}$ for 30 patients, and > $10 \mathrm{~mm}$ for 8 patients. No expulsion occurred in subjects with IUD-ED distance of $\leq 10 \mathrm{~mm}$, while there was 3 cases of expulsion in subjects with IUD-ED distance of $>10 \mathrm{~mm}$.

A too far distance of IUD-endometrium $(>10$ $\mathrm{mm}$ ) is one of the factor causing the expulsion of IUD $\mathrm{Cu}$ T-380A. Gabrielele Merki Feld in 2005, stated that the distance of IUD-Endometrium had great influence on the occurrence of expulsion. ${ }^{14}$ Fernandes and De Kroon also stated that the distance of IUD-ED of more than $10 \mathrm{~mm}$ would increase the occurrence of expulsion. 8,13

\section{CONCLUSION}

The incidence rate of IUD expulsion in IUD $\mathrm{Cu}$ T$380 \mathrm{~A}$ insertion right after vaginal delivery is $7.89 \%$. There is a correlation between IUD-ED distance with the occurrence of expulsion. In subjects with IUD-ED distance of $>10 \mathrm{~mm}$ the rate od expulsion was $37.5 \%$ of expulsion, while in subjects with IUD-ED distance of $\leq 10 \mathrm{~mm}$ there was no expulsion.

\section{REFERENCES}

1. Fowler RC. Postpartum Intrauterine Contraceptive Device (PPIUD) Services: A reference manual for providers. USA. November 2010

2. BKKBN. Analisis pencapaian program KB nasional. Analisisdan evaluasi hasil survey penduduk antar sensus (SUPAS) tahun 2005. Jakarta. BKKBN 2007: 34

3. Hartanto H. Safe Motherhood. Alat kontrasepsi dalam rahim. Keluarga Berencana dan Kontrasepsi. Jakarta, Pustaka Sinar Harapan. 2004: 24-6
4. BKKBN. Profil hasil pendataan keluarga tahun 2007. Badan Koordinasi Keluarga Berencana Nasional. Direktorat Pelaporan dan Statistik. Jakarta. 2008

5. Hartanto H. Tahap-tahap program KB nasional. Alat kontrasepsi dalam rahim. Keluarga berencana dan kontrasepsi. Jakarta, Pustaka Sinar Harapan. 2004: 20-1

6. BKKBN. Hasil pelaksanaan subsistem pencatatan dan pelaporan pelayanan kontrasepsi. Jakarta. 2010

7. Imbarwati. Beberapa faktor yang berkaitan dengan penggunaan KBIUD pada peserta KB non IUD di Kecamatan Pedurungan kota Semarang. Universitas Diponegoro. Semarang. 2009: 3

8. Fernandes JHA, Lippi UG. A clinical and ultrasound study on the use of postplacental intrauterine device. einstein. 2004; 2(2): 110-14

9. Weston MR, Martins SL, Neustadt AB, Gilliam ML. Factors influencing the uptake ofintrauterine devices among postpartum adolescents: a qualitative study. Am J Obstet Gynecol. 2012; 206(1): 40-1

10. Grimes DA, Lopez LM, Schulz KF, Van Vliet HAAM, Stanwood NL. The Cochrane Collaboration, Immediate post partum insertion of intrauterine devices (Review). New York, Jhon Wiley and Sons, Ltd. 2008. The Cochrane Library. 2010, Issue 5.

11 Zidenberg N, DeSilva N, Gilliam M, Espey E. Intrauterine Device and Adolescents. The American College of Obstetricians and Gynecologists: Women's Health Care Physicians vol 110, no 6, December 2007

12. WHO. Family Planning: A Global Handbook For Prividers 2011 Update. A WHO Family Planning Cornerstone. 2011

13. De Kroon CD, Van Houwelingen JC, Trimbos FW. The value of transvaginal ultrasound to monitor the position of an intrauterine device after insertion. A technology assessment study. Hum Reprod, 2003; 18 (11): 2323-7

14. Merki-Feld GS, Schwarz D, Imthurn B, Keller PJ. Partial and complete expulsion of the Multiload 375 IUD and the levonorgestrel-releasing IUD after correct insertion. Eur J Obstet Gynecol Reprod Biol. 2008; 137(1): 92-6

15. Valsky DV, Cohen SM, Celnikier DH, Sagie AL, Yagel S. The Shadow of the Intrauterine Device. J Ultrasound Med 2006; 25: 613-6

16. Peri N, Graham D, Levine D. Imaging of Intrauterine Contraceptive Devices. J Ultrasound Med 2007; 26: 1389-1401

17. Finger WR. IUD Insertion Timing Vital in Postpartum use. Family Health International. 1996;16(2): 9-18

18. Network, Summer. Dikutip dari Health Technology Assessment Indonesia. KB Pada Periode Menyusui (Hasil Kajian HTA Tahun 2009). Dirjen Bina Pelayanan Medik Kementrian Kesehatan Republik Indonesia. Juni 2010.

19. Tatum HJ, Ramos S. Immediate postplacental insertion of GYNE-T 380 and GYNE-T 380 postpartum intrauterine contraceptive devices: randomized study. Am J Obstet Gynecol 1996; 175: 1231-5

20. Celen S, Möröy P, Sucak A, Aktulay A, Danisman N. Clinical outcomes of early postplacental insertion of intrauterine contraceptive devices. Contraception. 2004; 69(4): 279-82

21. Chen BA, Reeves MF, Hayes JL, Hohmann HL, Perriera LK, Creinin MD. Postplacental or Delayed Insertion of the Levonorgestrel Intrauterine Device After Vaginal Delivery: A Randomized Controlled Trial. Obstet Gynecol 2010; 116: 1079-87 
22. Bednarek PH, Creinin MD, Reeves MF, Cwiak C, Espey E, Jensen JT. Immediate versus Delayed IUD Insertion after Uterine Aspiration. N Engl J Med 2011; 364: 2208-17

23. Zhang J, Feldblum PJ, Chi IC, Farr MG. Risk factors for copper T IUD expulsion: an epidemiologic analysis. Contraception. 1992; 46(5): 427-33

24. Allen RH, Goldberg AB, Grimes DA. Expanding access to intrauterine contraception. Am J Obstet Gynecol 2009; 201: 456.e1-5
25. Otero-Flores JB, Guerrero-Carreno FJ, Vazquez-Estrada LA. A comparative randomized study of three different IUDs in nulliparous Mexican women. Contraception 2003; 67: 273-6

26. Sivin I. Problems in the conduct and analysis of a comparative randomized study of three different IUDs in nulliparous Mexican women. Contraception 2004; 69: 259-60 